\title{
Green catalytic valorization of hardwood biomass into valuable chemicals with the use of solid catalysts
}

\author{
B.N. Kuznetsov ${ }^{1,2}$, N.V. Chesnokov ${ }^{1,2}$, O.V. Yatsenkova ${ }^{1}$, V.I. Sharypov ${ }^{1}$, N.V. Garyntseva ${ }^{1}$,
} N.M. Ivanchenko ${ }^{1}$, V.A. Yakovlev ${ }^{3}$

${ }^{1}$ Institute of Chemistry and Chemical Technology SB RAS, Akademgorodok, 50-24, Krasnoyarsk 660036, Russia

${ }^{2}$ Siberian Federal University, pr. Svobodniy, 79, Krasnoyarsk 660041, Russia

${ }^{3}$ Boreskov Institute of Catalysis SB RAS, pr. Lavrentieva, 5, Novosibirsk 630090, Russia

\begin{abstract}
Results of the study of green valorization of main components of hard wood biomass into valuable chemicals with the use of solid catalysts were described. The studied heterogeneous catalytic processes of hemicelluloses and cellulose hydrolysis, wood oxidative fractionation, lignin depolymerization in supercritical spirits was suggested to employ for the green biorefinery of hardwood with producing of xylose, pure cellulose, glucose, alcohols and liquid hydrocarbons.
\end{abstract}

Keywords: hardwood biomass, green biorefinary, valuable chemicals, solid catalysts.

\section{Introduction}

In recent years the new processes for obtaining the alternative fuels and chemicals from renewable lignocellulosic biomass are intensively studied (Clark and Deswarte 2008; Nelson 2011). Wood waste and low-quality wood create a reliable source of renewable raw material for large-scale production of chemicals and alternative fuels.

In principle, from main components of wood biomass it is possible to produce all range of products of modern petrochemical synthesis, and also unique natural compounds, like biologically active substances.

Biomass of various tree species consists of cellulose, lignin, hemicelluloses, extracted substances and insignificant quantity of inorganic components (Fengel and Wegener 1984). Cellulose represents the linear polysaccharide constructed of links of glucose, connected by $\beta-1,4$ bonds. Hemicelluloses are the branched polysaccharides generally constructed of pentoses and hexoses with shorter, than in cellulose, chains. The lignin is polymer with branched structure which macromolecules are constructed by substituted phenylpropane units.

The specified types of vegetable polymers are structured by complex way in plant cells and therefore are quite stable against chemical reagents and enzymes. In this regard, in 
traditional processes of lignocellulose biomass conversion the chemically aggressive and ecologically dangerous reagents, increased temperatures and pressures are applied.

For this reason, the traditional technologies of wood processing have a low productivity, produce only limited range of products and negatively influence on an environment. In particular, conventional technologies of cellulose production use the ecologically dangerous sulfur and chlorine-containing delignification agents (Sixta 2006). Also they don't allow to provide simultaneous producing the commodity products from such wood components, as lignin, hemicelluloses, extractive substances.

Traditional technologies of wood hydrolysis use mineral acids as catalysts and they became outdated and don't meet the modern requirements for productivity, power consumption, resource-saving and ecological purity.

New effective methods for the production valuable chemicals, functional polymers and biofuels from lignocellulose biomass are based on the use of effective catalysts and "green" reagents (Bessone et al. 2014; Serrano-Ruiz and Dumesic 2011; Zakzeski et al. 2010).

The studies, directed on integrated catalytic processing of biomass into biofuels and chemicals are intensified in the last decade (Cherubini et al. 2009; de Long et al. 2013). The most perspective integrated processes include, as a key stage, biomass fractionation on polysaccharides and lignin. Their further conversion allows to produce various chemicals and liquid biofuels.

Known ways of lignocelluloses biomass fractionation can be united into two groups. In one of them cellulose and hemicelluloses are removed by dissolution, and the lignin remains as an insoluble rest, another includes methods in which the lignin is dissolved. The first group includes wood hydrolysis processes, and the second - processes of cellulose isolation from wood.

Single-stage processes of wood fractionation on cellulose and soluble lignin by oxidative depolymerization of lignin in "hydrogen peroxide-acetic acid-water" medium at $120-130{ }^{\circ} \mathrm{C}$ in the presence of different catalysts were studied (Kuznetsov et al. 2008a). At optimum conditions of wood delignification by hydrogen peroxide in the presence of $\mathrm{H}_{2} \mathrm{SO}_{4}$ catalysts $(2 \mathrm{wt} \%)$ and $\mathrm{TiO}_{2}(0,5 \mathrm{wt} \%)$ the cellulosic products containing less than $1 \%$ of a residual lignin can be obtained with an acceptable yield (44-48 wt\% on abs. dry wood).

Perspective directions of lignocellulosic biomass processing are connected with the use of solid catalysts which have a number of technological advantages in comparison with the dissolved catalytic systems (Van de Vyver et al. 2011; Maki-Arvela et al. 2007; Raveendran and Guliants 2009). 
This presentation describes results of the study of heterogeneous catalytic processes of green valorization of low-quality birch and aspen wood to valuable chemicals, namely hydrolysis of hemicelluloses into xylose, oxidative fractionation of wood on pure cellulose and soluble lignin, hydrolysis of cellulose into glucose, depolymerization of acetone-lignin in supercritical butanol with the formation of liquid hydrocarbons. The combination of studied processes in a single technological cycle can be employed for the green biorefinery of hardwood into valuable chemicals.

\section{Experimental}

Air dry sawdust (fraction 2-5 mm) of birch wood (Betula pendula) with composition (wt\%): cellulose - 46.5, hemicelluloses - 27.2, lignin 21.8 and aspen wood (Populas tremula L.) with composition (wt\%): cellulose 46.3, hemicelluloses 24.5, lignin 21.9 were used in experiments.

Acetone-lignin, isolated by boiling acetone from aspen wood after hydrolysis of wood hemicelluloses (Boeriu et al. 2014) was used in experiments on the lignin depolymerization in supercritical butanol. Yield of acetone-lignin is $21 \mathrm{wt} \%$ from amount of lignin in aspen wood. Obtained acetone-lignin is completely dissolved in twofold excess of boiling butanol. Acetonelignin chemical composition (wt\%): $\mathrm{C}-67.2, \mathrm{H}-6.7, \mathrm{O}-25.1$, ash -0.4 .

The catalytic processes of wood hemicelluloses and cellulose hydrolysis oxidative fractionation of wood on cellulose and lignin, lignin conversion in supercritical butanol were studied with the use of batch stirring reactors and rotating autoclaves.

\section{Hydrolysis of wood hemicelluloses}

In hydrolysis with $\mathrm{H}_{2} \mathrm{SO}_{4}$ catalyst the glass batch reactor of $500 \mathrm{~cm}^{3}$ volume supplied by mechanical stirrer, condenser and thermometer was used. Air-dry wood sawdust (fraction 2-5 $\mathrm{mm}$ ) in the amount $10 \mathrm{~g}$ and $80 \mathrm{ml} \mathrm{1-4} \mathrm{wt} \% \mathrm{H}_{2} \mathrm{SO}_{4}$ (GOST 4204-77) were placed into the reactor. The reaction mixture was vigorously stirred $(700 \mathrm{rpm})$ at $100{ }^{\circ} \mathrm{C}$ during $1-5 \mathrm{~h}$. When the reaction was completed, the reaction mixture was cooled to room temperature and filtered under vacuum using a Buchner funnel. Obtained hydrolysate was analysed on gas chromatograph "VARIAN-450". Solid wood residue was washed with distilled water and dried at $105{ }^{\circ} \mathrm{C}$ until constant weight. Conversion of wood was estimated by the gravimetric method.

For wood hemicelluloses hydrolysis with solid catalysts the rotating steel autoclave with an inner Tefloh tube of $35 \mathrm{ml}$ volume was used. The mixture of wood sawdust activated in planetary mill AGO-2 during $30 \mathrm{~min}$ and solid catalyst (fraction less $0.5 \mathrm{~mm}$ ) with weight ratio 1:1 was placed into Teflon tube and distilled water was added. The concentration of wood in 
water was $40 \mathrm{~g} / \mathrm{l}$. The hydrolysis reaction was carried out at $110-170{ }^{\circ} \mathrm{C}$ at the speed of rotation of the autoclave $120 \mathrm{rpm}$. The procedures of reaction mixture fractionation and analysis were the same as in the case of wood hydrolysis with $\mathrm{H}_{2} \mathrm{SO}_{4}$.

\section{Hydrolysis of cellulose with acid solid catalysts}

Rotating steel autoclave with an inner Teflon tube of $35 \mathrm{ml}$ volume was used for cellulose hydrolysis at $150{ }^{\circ} \mathrm{C}$ and $170{ }^{\circ} \mathrm{C}$. Cellulose $(0.45 \mathrm{~g})$ and solid catalyst $(0.45 \mathrm{~g})$ were placd into Teflon tube and distiied water was added. Procedures of cellulose hydrolysis and hydrolysates analysis were the same as in the case of hemicelluloses hydrolysis with solid acid catalysts.

\section{Conversion of lignin in butanol}

The termal conversion of acetone-lignin in supercritical butanol was carried out at 250 $350{ }^{\circ} \mathrm{C}$ in a rotating autoclave (Autoclave Engineers, USA) of $300 \mathrm{~cm}^{3}$ volume. A mixture $3 \mathrm{~g}$ lignin and $0.3 \mathrm{~g}$ catalyst crushed to the size of the particles $<0.1 \mathrm{~mm}$ and $15 \mathrm{ml}$ of butanol was placed in the autoclave. The autoclave was hermetically sealed. Air was removed from the autoclave by purging it with argon through its stop valves. Thereafter, the autoclave was heated at a rate of $10 \mathrm{C} / \mathrm{min}$ to the desired temperature and was kept at this temperature for $1 \mathrm{~h}$ under vigorous mixing $(850 \mathrm{rpm})$. Under these conditions, the pressure in the autoclave was 4.8-5.0 MPa. Then the autoclave was cooled to room temperature and the products were quantitatively washed out of the autoclave with hexane. The condensed products were filtered through a filter paper (blue ribbon) in a vacuum using a Büchner funnel. The filtration residue was sequentially extracted with hexane, diethyl ether and acetone. The extract was brought to constant weight by drying under vacuum at room temperature. Yield of extracts and solid residues were determined by the gravimetric method after solvent removal.

\section{Oxidative fractionation of wood}

Catalytic delignification of wood sawdust by $\mathrm{H}_{2} \mathrm{O}_{2}$ was carried out as in (Kuznetsov et al. 2013a) using $250 \mathrm{~cm}^{3}$ glass reactor equipped with mechanical stirrer, reflux condenser and thermometer. Wood sawdust (10 g) was placed to glass reactor. Then, a mixture of glacial acetic acid, hydrogen peroxide, distilled water and $\mathrm{TiO}_{2}$ was added. The reaction mixture was vigorously stirred $(700 \mathrm{rpm})$ at selected temperature $\left(70-100{ }^{\circ} \mathrm{C}\right)$ during $1-4 \mathrm{~h}$. Composition of the of reaction mixture was varied in the following range: hydrogen peroxide $3-7 \mathrm{wt} \%$, acetic acid 15-40 wt \%, liquid/wood ratio (LWR) - 10-15. Concentration of $\mathrm{TiO}_{2}$ catalyst was at $1 \mathrm{wt} \%$. Commercial $\mathrm{TiO}_{2}$ (GOST 9808-84) with an average particle size of about 10 microns, rutile phase composition and BET surface area $3 \mathrm{~m}^{2} / \mathrm{g}$ was used as the catalyst. When the reaction was 
completed, the solid product was separated under vacuum using Buchner funnel, following by washing distilled water and drying at $105{ }^{\circ} \mathrm{C}$ until constant weight.

Such parameter as the residual lignin content in cellulosic product was used to evaluate the delignification activity of $\mathrm{TiO}_{2}$ catalyst.

The cellulosic product yield was estimated by gravimetric method and calculated as follows: $\mathrm{Y}=\left(\mathrm{m} / \mathrm{m}_{\mathrm{o}}\right) \times 100$, where $\mathrm{Y}-$ yield of cellulosic product, wt $\% ; \mathrm{m}-$ weight of abs. dry cellulosic product, $\mathrm{g} ; \mathrm{m}_{\mathrm{o}}-$ weight of abs. dry wood, $\mathrm{g}$.

\section{Analysis of liquid and solid products}

\section{Analysis of hydrolysates}

Individual composition and content of monosaccharides in hydrolysates obtained from hemicelluloses and cellulose were determined using a gas chromatograph "VARIAN-450 GC" with a flame ionization detector and with capillary column VF-624 ms $30 \mathrm{~m}$ length, inner diameter $0.32 \mathrm{~mm}$. Conditions of the analysis: carrier gas helium, temperature of injector $250{ }^{\circ} \mathrm{C}$, temperature of detector $280^{\circ} \mathrm{C}$, initial temperature of column $50{ }^{\circ} \mathrm{C}$, temperature rise up to 180 ${ }^{\circ} \mathrm{C}$ at a speed $10{ }^{\circ} \mathrm{C} / \mathrm{min}$, aging at $180{ }^{\circ} \mathrm{C}$ during $37 \mathrm{~min}$. The duration of chromatographic separation of monosaccharides was $55 \mathrm{~min}$. To register the release of oligosaccharides the temperature of column was raised up to $250{ }^{\circ} \mathrm{C}$ and kept $30 \mathrm{~min}$. Total time of hydrolysates analysis was $92 \mathrm{~min}$. Before analysis the sample of hydrolysate was subjected to derivatization with the formation of trimethylsilyl derivatives of monosaccharides using the mixture of trimethylchlorosilan and hexamethyldisilazane in pyridine medium according to [Ruiz-Matute et al. 2011). Sorbitol was used as an inner standart.

Impurities of furfural, 5-hydroxymethyl-furfural and levulinic acid in hydrolysates were determined by HPLC method using chromatograph "Milichrom A-02" (Econova, Novosibirsk) with scanning spectrophotometric detector UV range 190-360 nm. Column made of stainless steel $(2.0 \times 75 \mathrm{~mm})$ and packed with silica gel Pronto SIL-120-5-C18 AQ with a grain size of $5.0 \mu \mathrm{m}$ was used. Temperature of the column $35{ }^{\circ} \mathrm{C}$ was kept. Mobile phase: acetonitrile and deionized water (3:97), flow rate $100 \mathrm{mcl} / \mathrm{min}$. The time of analysis $17 \mathrm{~min}$. Standarts for the analysis of hydrolysates are glucose (GOST 975-88), D-xylose 142080.1208 (Panreac), D-mannose 373195.1208 (Panreac), D-sorbit (Panreac), furfural (GOST 10930-74), 5-hydroxymethyl-2-furaldehyde, $99 \%$ (Aldrich), levulinic acid, $99 \%$ (Aldrich).

The liquid hydrocarbon products were analyzed by GC-MS using Agilent 7890A chromatograph fitted with an Agilent 7000A Triple Quad mass-selective detector (Agilent, United States) by recording the total ion current. The products were separated in an HP-5MS 
capillary column (30 $\mathrm{m}$ in length, $0.25 \mathrm{~mm}$ in inner diameter) in the temperature programmed mode while raising the temperature from 40 to $250^{\circ} \mathrm{C}$ at a rate of $3^{\circ} \mathrm{C} / \mathrm{min}$. $\mathrm{Cu}-\mathrm{Ka}$ source $(\mathrm{A}=0,154 \mathrm{~nm})$ in the $2 \theta$ range $5-70^{\circ}$ and scanning step width of $0,01 \% \mathrm{scan}$. The cellulose samples were analyzed by the powder method in cuvette with $2,5 \mathrm{~cm}$ diameter. Crystallinity index (CI) was calculated from the ratio of the height between the intensity of the crystalline peak and total intensity after subtraction of the background signal (Park et al. 2010): CI $=\left(\mathrm{I}_{002}-\mathrm{I}_{\mathrm{AM}}\right) /\left(\mathrm{I}_{002}\right)$, where $\mathrm{I}_{002}-$ is the height of the 002 peak; $\mathrm{I}_{\mathrm{AM}}-$ is the height of the minimum between the 002 and the 101 peaks.

Infrared spectroscopy analysis (FTIR) was carried out in transmission mode. Samples of cellulose (4 mg for each) were prepared in tablets with matrix $\mathrm{KBr}$. The spectra were recorded with Bruker Tensor -27 in the range of wavelength $4000-400 \mathrm{~cm}^{-1}$. Spectral data were processed by the program OPUS/YR (version 2.2).

The content of cellulose, hemicelluloses and lignin in the products was defined by chemical methods generally accepted in wood chemistry (Sjoöstroöm and Alern 1999).

\section{Results and discussion}

\section{Catalytic hydrolysis of birch wood hemicelluloses}

In order to select the conditions of hydrolysis of birch wood hemicelluloses, providing a high yield of xylose the catalytic properties of sulfuric acid and solid acid catalysts were compared. At fixed temperature $100^{\circ} \mathrm{C}$ and liquid wood ratio 8 the concentration of sulfuric acid catalyst was varied between $1-4 \mathrm{wt} \%$ and time of hydrolysis from 1 to $5 \mathrm{~h}$. It was found that the conversion of wood increases with increasing duration of hydrolysis and concentration of $\mathrm{H}_{2} \mathrm{SO}_{4}$ catalyst (Fig. 1). Conversion of wood reaches 35.1-36.9 wt $\%$ at $\mathrm{H}_{2} \mathrm{SO}_{4}$ concentration 3 and 4 $\mathrm{wt} \%$ and time of hydrolysis $5 \mathrm{~h}$.

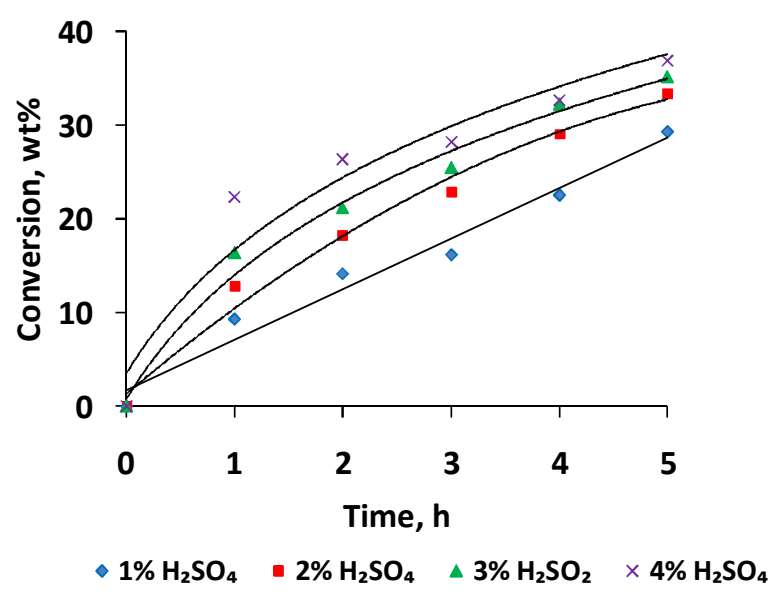

200 Fig. 1 Impact of $\mathrm{H}_{2} \mathrm{SO}_{4}$ catalyst concentration on the conversion of birch wood in hydrolysis at $201 \quad 100{ }^{\circ} \mathrm{C}$ 

concentration and hydrolysis time reaching $77 \%$ for $3 \% \mathrm{H}_{2} \mathrm{SO}_{4}$ after $5 \mathrm{~h}$ (Fig. 2).

204

205

206

207

208

209

210

211

212

213

214

215

216

217

218

219

220

221

222

223

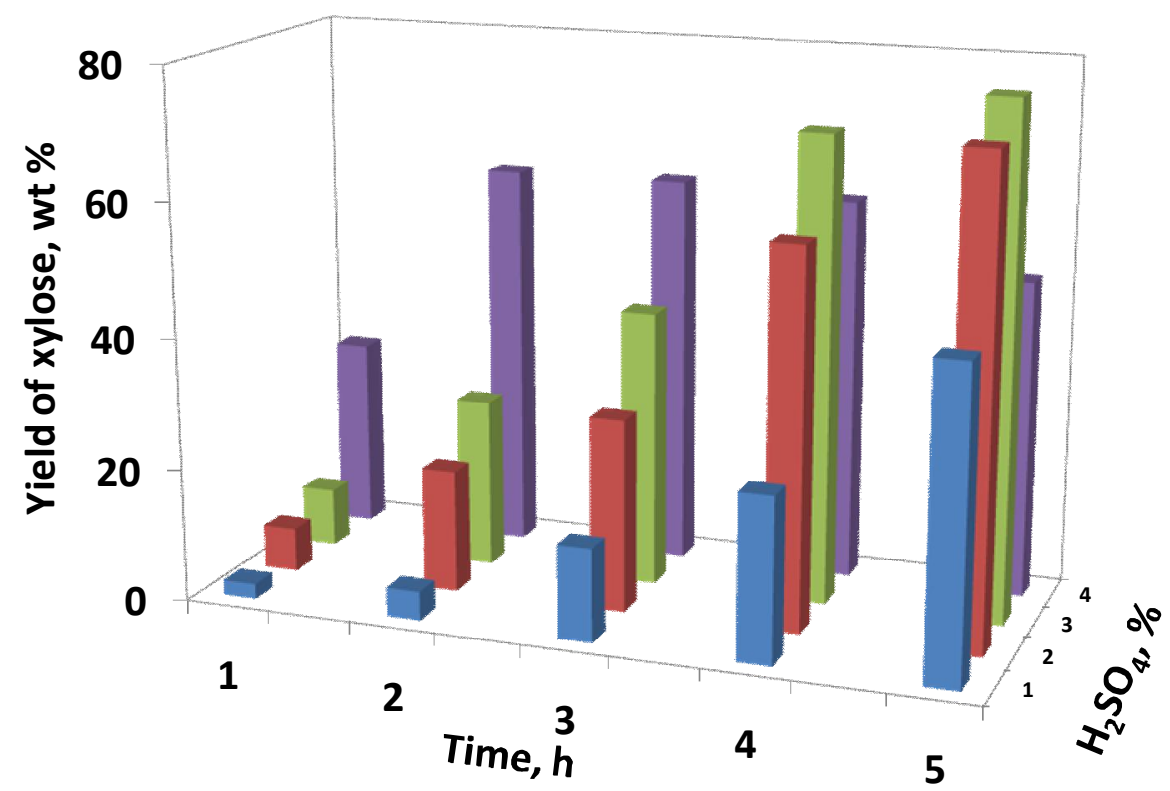

Fig. 2 Influence of $\mathrm{H}_{2} \mathrm{SO}_{4}$ concentration and time of birch wood hydrolysis at $100{ }^{\circ} \mathrm{C}$ on the yield of xylose

Catalyst $4 \% \mathrm{H}_{2} \mathrm{SO}_{4}$ gives the high yields of xylose (58.2-59.2 wt\%) after hydrolysis during 2-4 h. But the increase of hydrolysis time to $5 \mathrm{~h}$ reduces the yield of xylose to $48 \mathrm{wt} \%$ due to its further transformation into furan compounds (Taherzadeh and Karimi 2007).

The following sugars are also formed: mannose $(0.12-3.6 \mathrm{wt} \%)$ and glycose (0.9-12.7 wt\%) depending on wood hydrolysis conditions.

Solid catalysts were active in hydrolysis of beech wood hemicelluloses only at temperatures higher $100^{\circ} \mathrm{C}$. Catalytic properties of SBA- 15 with $-\mathrm{SO}_{3} \mathrm{H}$ groups $\left(\mathrm{S}_{\mathrm{BET}} 417 \mathrm{~m}^{2} / \mathrm{g}\right)$, $\mathrm{ZrO}_{2}$ with $\mathrm{SO}_{4}{ }^{2-}$ groups $\left(\mathrm{S}_{\mathrm{BET}} 110 \mathrm{~m}^{2} / \mathrm{g}\right)$, ion exchange resins Amberlite ${ }^{\circ}$ IR 120 , Amberlyst ${ }^{\circledR}$ 15 dry $\left(\mathrm{S}_{\mathrm{BET}} 53 \mathrm{~m}^{2} / \mathrm{g}\right)$ and KU-2-8 were studied in birch wood hemicelluloses hydrolysis at 110 $170{ }^{\circ} \mathrm{C}$.

To ensure the effective contact between wood and solid catalyst the mixture before reaction was ground to a particle size of $0.1-0.25 \mathrm{~mm}$ in the mill-activator AGO-2 during $0.5 \mathrm{~h}$.

The maximum yield of xylose $(72 \mathrm{wt} \%)$ was obtained at $150{ }^{\circ} \mathrm{C}$ with sulphated $\mathrm{ZrO}_{2}$ catalyst (Fig. 3). This yield is comparable to that obtained in the case of wood hydrolysis with $3 \% \mathrm{H}_{2} \mathrm{SO}_{4}$ catalyst at $100{ }^{\circ} \mathrm{C}$. At temperature $170{ }^{\circ} \mathrm{C}$ the hydrolysis of cellulose also takes place with the formation of glucose. 

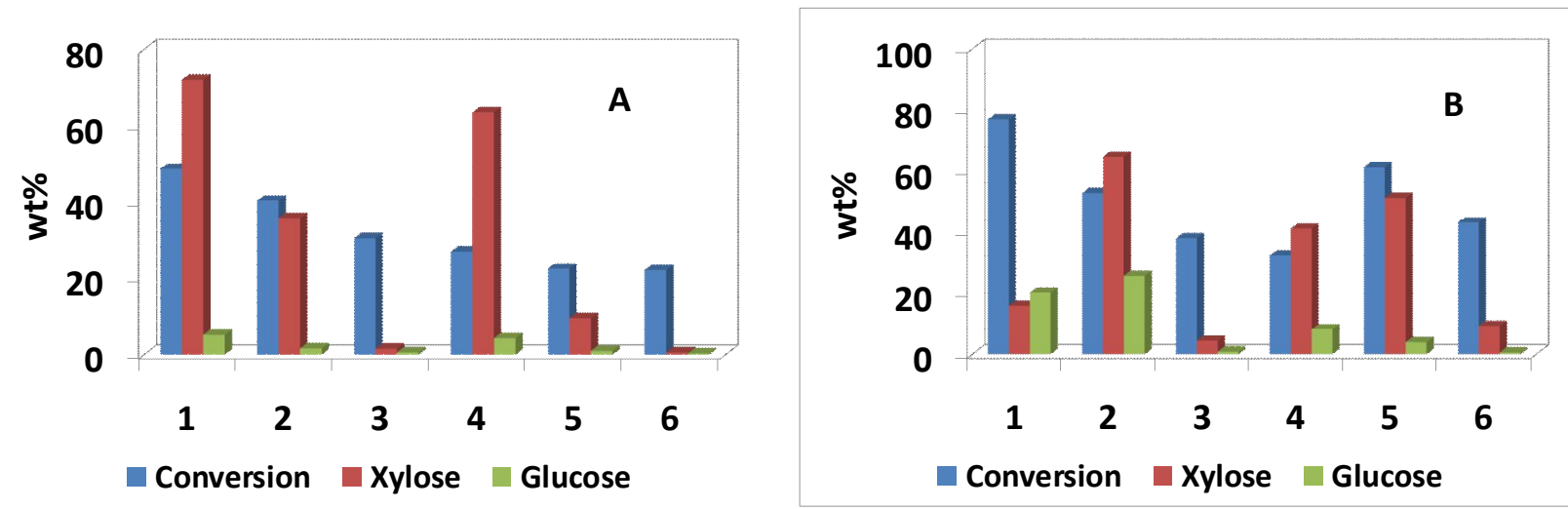

224

225

226

227

228

229

230

231

232

233

234

235

236

237

238

239

240

241

242

243

244

245

246

247

248

249

250

251

252

Fig. 3 Effect of solid catalysts on the conversion of birch wood and on the yield of xylose and glucose at $150{ }^{\circ} \mathrm{C}(\mathrm{A})$ and at $170{ }^{\circ} \mathrm{C}(\mathrm{B})(\mathrm{wood} /$ catalyst wt. ratio $=1)$

$1-\mathrm{ZrO}_{2} / \mathrm{SO}_{4}{ }^{2-}, 2-\mathrm{SBA}-15$ with $-\mathrm{SO}_{3} \mathrm{H}, 3$ - Amberlite ${ }^{\circledR} \mathrm{IR} 120$ with $-\mathrm{SO}_{3} \mathrm{H}, 4$ - Amberlyst ${ }^{\circledR}$ 15 dry with $-\mathrm{SO}_{3} \mathrm{H}, 5-\mathrm{KU}-2-8$ with $-\mathrm{SO}_{3} \mathrm{H}, 6$-without catalyst

\section{Oxidative fractionation of birch wood}

The processes of organosolv delignification with environmentally safe oxidants $\left(\mathrm{O}_{2}\right.$, $\mathrm{H}_{2} \mathrm{O}_{2}$ ) (Suchy and Argyropoulos 2001) can be successfully used for wood fractionation on cellulose and lignin for their subsequent processing to chemicals and biofuels.

Some complexes of the transition metals, for example polyoxometalates, can catalyze the processes of pulp and wood delignification by oxygen (Gaspar et al. 2007). However the application of these catalysts is complicated by their high cost and complexity of regeneration for the reuse.

In oxidative delignification of wood by $\mathrm{H}_{2} \mathrm{O}_{2}$ in acetic acid-water solvent, sulfuric acid catalyst is used [Kuznetsov et al. 2013a). But $\mathrm{H}_{2} \mathrm{SO}_{4}$ catalyst has such technological disadvantages as high toxicity and corrosion activity. At elevated temperature $\left(120-130{ }^{\circ} \mathrm{c}\right)$ the more technologically convenient solid $\mathrm{TiO}_{2}$ can be applied in delignification of wood by $\mathrm{H}_{2} \mathrm{O}_{2}$ (Kuznetsov et al 2008b). Advantages of $\mathrm{TiO}_{2}$ application as delignification catalyst are stipulated by the absence of corrosion activity and toxicity, by its availability, low cost and lack of need for its separation from reaction products.

In wood delignification processes at elevated temperatures the side reactions of soluble mass products condensation with the formation of so-called "pseudo-lignin" ( $\mathrm{Hu}$ et al. 2012) take place. The contribution of condensation reactions can be reduced by the acceleration of a diffusion of lignin depolymerization products from wood particles into solution and by reduction of delignification temperature.

It was shown that the use of small particles of wood, high liquid to wood ratio (LWR) and the intensive mixing of the reaction solution allows to reduce the externally diffusion limitations and to provide a high rate of aspen wood delignification by $\mathrm{H}_{2} \mathrm{O}_{2}$ under mild 
conditions $\left(70-100{ }^{\circ} \mathrm{C}\right.$, atmospheric pressure) in the presence of $2 \% \mathrm{H}_{2} \mathrm{SO}_{4}$ catalyst (Kuznetsov et al 2013a).

The possibility of successful replacement under mild conditions the $\mathrm{H}_{2} \mathrm{SO}_{4}$ catalyst on non-toxic and non-corrosive solid $\mathrm{TiO}_{2}$ catalyst in the oxidative fractionation of birch wood on cellulose and soluble lignin was shown in the present paper. The optimal process conditions providing a high yield of pure cellulose were determined.

To optimize the process of birch wood oxidative fractionation over mild conditions in the presence of $\mathrm{TiO}_{2}$ catalyst the influence of temperature, concentrations of hydrogen peroxide and acetic acid, liquid/wood ratio, time on the dynamics of lignin removal from wood was studied.

The increase of temperature, concentrations of $\mathrm{H}_{2} \mathrm{O}_{2}$ and $\mathrm{CH}_{3} \mathrm{COOH}$ in the reaction mixture significantly reduces the content of residual lignin and of hemicelluloses in the cellulosic product (Fig. 4, Table 1). But at the same time the yield of cellulosic product is decreased.
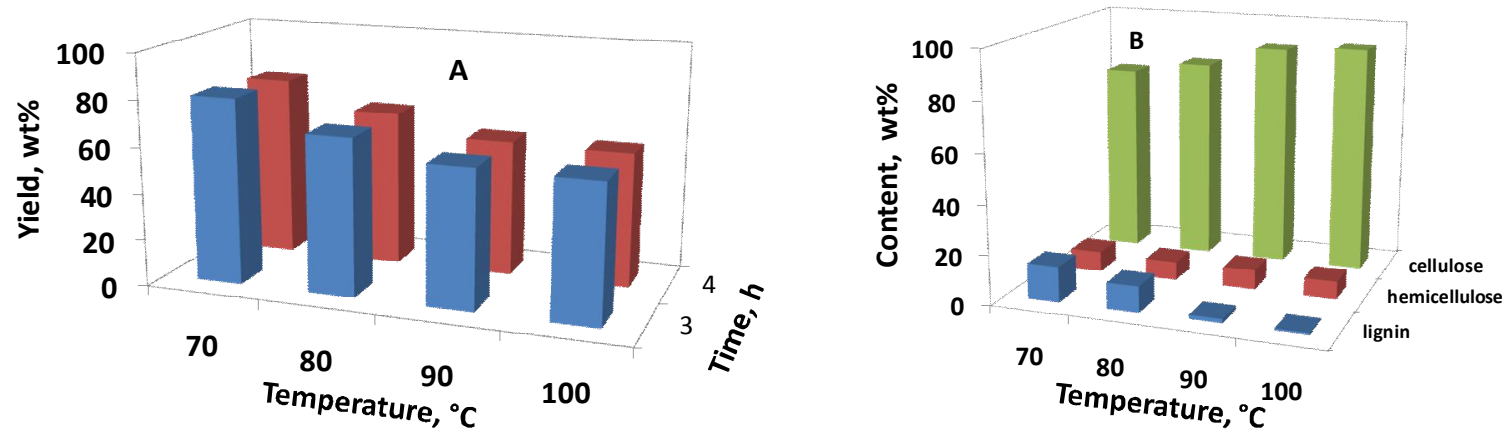

Fig. 4 Effect of delignification temperature on the yield (A) and composition (B) of cellulosic product from birch wood $\left(\mathrm{CH}_{3} \mathrm{COOH} 25 \mathrm{wt} \%, \mathrm{H}_{2} \mathrm{O}_{2} 5 \mathrm{wt} \%, \mathrm{TiO}_{2} 1 \mathrm{wt} \%\right.$, LWR = 10)

Table 1 Effect of concentration of $\mathrm{H}_{2} \mathrm{O}_{2}$ and $\mathrm{CH}_{3} \mathrm{COOH}$ on the yield and composition of cellulosic product obtained from birch wood at $100{ }^{\circ} \mathrm{C}$ and time $4 \mathrm{~h}$

\begin{tabular}{lccccccc}
\hline & \multicolumn{4}{c}{$\mathrm{H}_{2} \mathrm{O}_{2}, \mathrm{wt} \%$} & \multicolumn{3}{c}{$\mathrm{CH}_{3} \mathrm{COOH}, \mathrm{wt} \%$} \\
\cline { 2 - 8 } & 3 & 4 & 5 & 6 & 15 & 25 & 35 \\
\hline Yield,wt\% & 67.5 & 60.8 & 56.7 & 56.5 & 73.3 & 56.7 & 58.2 \\
Composition, wt\%: & & & & & & & \\
cellulose & 82.1 & 87.8 & 90.7 & 92.3 & 83.7 & 90.7 & 92.3 \\
hemicelluloses & 9.8 & 8.2 & 7.5 & 6.7 & 8.8 & 7.5 & 6.9 \\
lignin & 7.8 & 3.7 & 1.5 & 0.7 & 7.2 & 1.5 & 0.5 \\
\hline
\end{tabular}

The increase of temperature from $70{ }^{\circ} \mathrm{C}$ to $100{ }^{\circ} \mathrm{C}$ reduces the contents of lignin and hemicelluloses in the cellulosic product and the yield of product.

Acetic acid is used in the reaction mixture to facilitate the dissolution of the products of lignin oxidative depolymerization. When $\mathrm{CH}_{3} \mathrm{COOH}$ concentration in reaction medium is less than $20 \mathrm{wt} \%$ the obtained cellulosic product has a high content of residual lignin. 
The increase of LWR from 5 to 15 only slightly affects on the yield and composition of cellulosic product.

The kinetic study of birch wood delignification by $\mathrm{H}_{2} \mathrm{O}_{2}$ with $\mathrm{TiO}_{2}$ catalyst in the temperature range $70-100{ }^{\circ} \mathrm{C}$ was accomplished. The variation of lignin concentration in the cellulosic product was used for calculating the rate constants of delignification process. It was found that the process of oxidative delignification of birch wood by $\mathrm{H}_{2} \mathrm{O}_{2}$ in the presence of $\mathrm{TiO}_{2}$ catalyst is described satisfactory by the first order equations.

The calculated rate constants of birch wood oxidative delignification with catalyst $\mathrm{TiO}_{2}$ are presented in Table 2 .

Table 2 Rate constants of birch wood delignification (reaction conditions: $\mathrm{H}_{2} \mathrm{O}_{2}-5 \mathrm{wt} \%$, $\mathrm{CH}_{3} \mathrm{COOH}-25 \mathrm{wt} \%$, catalyst $\mathrm{TiO}_{2}-1 \mathrm{wt} \%$, LWR - 15)

\begin{tabular}{cc}
\hline Temperature, ${ }^{\circ} \mathrm{C}$ & $\mathrm{k} \cdot 10^{-4}, \mathrm{c}^{-1}$ \\
\hline 70 & 0.40 \\
80 & 0.78 \\
90 & 2.10 \\
100 & 2.72 \\
\hline
\end{tabular}

289

290

291

292

293

The activation energy of birch wood oxidative delignification process was determined using temperature dependence of the rate constants in Arrhenius coordinates (Fig. 5). The rather high value of activation energy $\left(84 \mathrm{~kJ} \cdot \mathrm{mol}^{-1}\right)$ points on the absence a noticeable effect of external diffusion limitations at the used conditions of birch wood oxidative delignification with $\mathrm{TiO}_{2}$ catalyst.

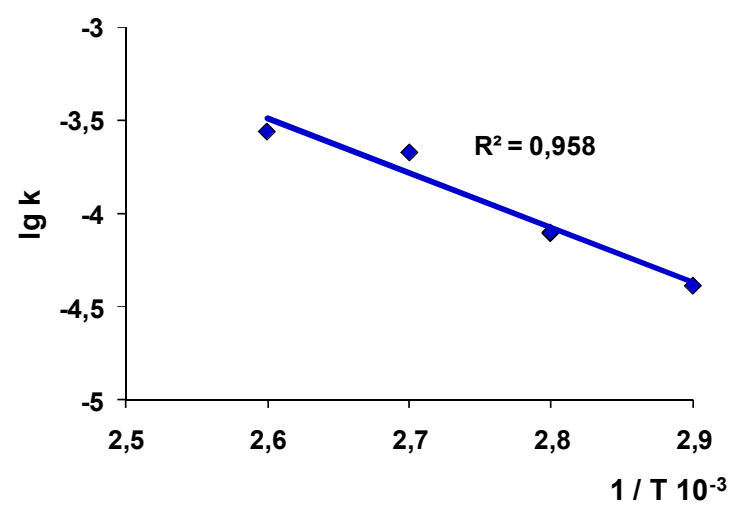

Fig. 5 Temperature dependence of rate constants of birch-wood delignification

Cellulosic product obtained by oxidative fractionation of birch wood sawdust at optimal condition $\left(100{ }^{\circ} \mathrm{C}, \mathrm{H}_{2} \mathrm{O}_{2}-5 \mathrm{wt} \%, \mathrm{CH}_{3} \mathrm{COOH}-25 \mathrm{wt} \%\right.$, LWR -15$)$ with an yield $48.2 \mathrm{wt} \%$ was studied. The composition of cellulosic product (wt\%): cellulose 93.7, hemicelluloses 5.5, lignin 0.5. According to the FTIR and XRD data the structure of cellulose obtained at optimal conditions of birch-wood fractionation corresponds to that of commercial microcrystalline cellulose (Fig. 6, 7). 


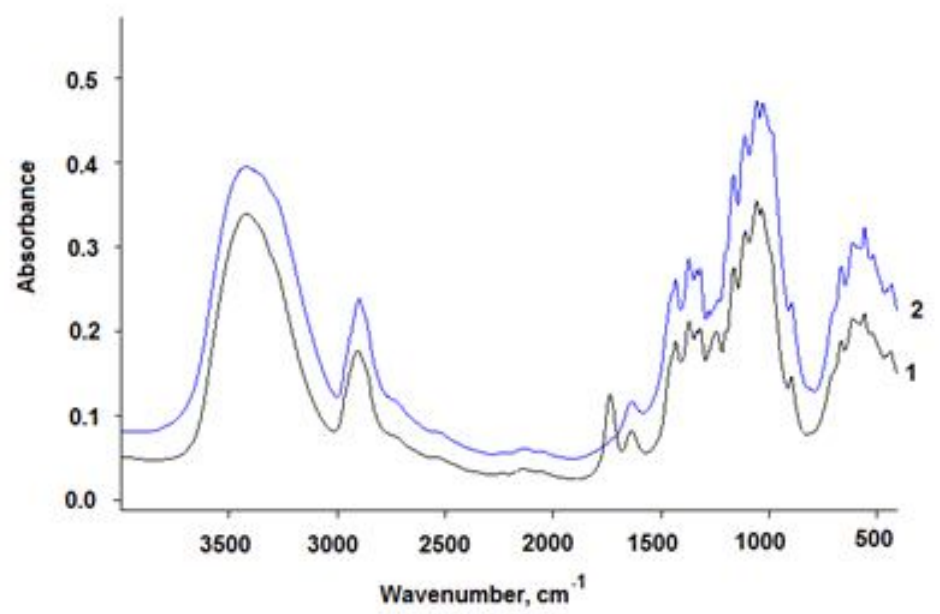

Fig. 6 FTIR spectra of cellulose from birch wood (1) and commercial microcrystalline cellulose Vivapur (2)

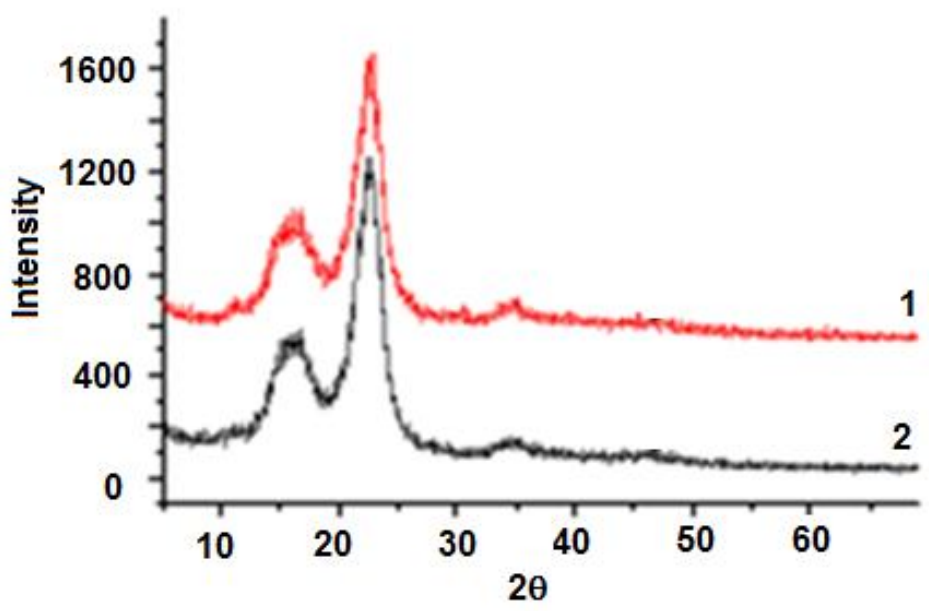

Fig. 7 Diffraction patterns of cellulose from birch wood (1) and commercial microcrystalline cellulose Vivapur (2)

Crystallinity index of cellulose from birch wood, calculated from the ratio of height between the intensity of the crystalline peak and total intensity (Park et al. 2010) is equal to 0.75. According to GC-MS data the soluble products of birch wood oxidative fractionation contain only small amounts of aromatic compounds, indicating deep oxidation of phenylpropane units of lignin at studied process conditions. It is possible that the hydroxyl and peroxide radicals generated from $\mathrm{H}_{2} \mathrm{O}_{2}$ on the surface of $\mathrm{TiO}_{2}$ catalyst can diffuse through the liquid reaction medium to the wood particles and to execute the oxidative destruction of lignin via homolytic mechanism.

Thus, the results of the study demonstrate the possibility of effective fractionation of hard wood biomass into pure cellulose and soluble products from lignin under mild conditions $\left(100^{\circ} \mathrm{C}\right.$, atmospheric pressure) in the medium " $\mathrm{H}_{2} \mathrm{O}_{2}-\mathrm{CH}_{3} \mathrm{COOH}-\mathrm{H}_{2} \mathrm{O}-\mathrm{TiO}_{2}$ catalyst". 
The glucose-containing hydrolysates for biotechnological synthesis are mainly produced

326

327

328

330

331

332

333

334

335

336

337

338

339

340

341

342

343

344 345

in industry by high-temperature catalytic hydrolysis of wood with dilute sulfuric or hydrochloric acid (Zheng et al. 2009). The resulting hydrolysates are contaminated by products of lignin and hemicelluloses destruction, that requires time and labor consuming purification of wood hydrolysates before using.

The yeast used in the enzymatic synthesis of ethanol can assimilate only hexose sugars, while pentose sugars inhibit the process. It is, therefore, necessary to remove the pentosancontaining hemicelluloses from lignocellulosic biomass for increasing the ethanol yield.

Cellulose obtained by catalytic oxidative fractionation of wood can be used for the production of pure glucose hydrolysates for alcohols synthesis. As known from the literature [Besson et al. 2014] the solid acid catalysts are active in hydrolysis of cellulose at $150-180{ }^{\circ} \mathrm{C}$. The used catalysts should be stable in water under elevated temperatures. In this paper the catalytic properties of mesoporous catalyst SBA-15, containing $-\mathrm{SO}_{3} \mathrm{H}$ groups were studied in the hydrolysis of cellulose at $150{ }^{\circ} \mathrm{C}$. Texture characteristics of acid SBA-15 catalyst: surface area $370 \mathrm{~m}^{2} / \mathrm{g}$, total volume of pores $0.2 \mathrm{~cm}^{3} / \mathrm{g}$, average diameter of pores $2.0 \mathrm{~nm}$.

The mechanical treatment of cellulose was used to decrease the cellulose crystallinity. Mechanical activation of cellulose in planetary mill AGO-2 during $1 \mathrm{~h}$ reduces the degree of its polymerization from 350 to 185 and the crystallinity index from 0.75 to 0.35 . It was established by scanning microscopy that the structure of cellulose after activation becomes more homogeneous and the average particle size decreased from 60-70 $\mu \mathrm{m}$ to $10-15 \mu \mathrm{m}$ (Fig. 8).

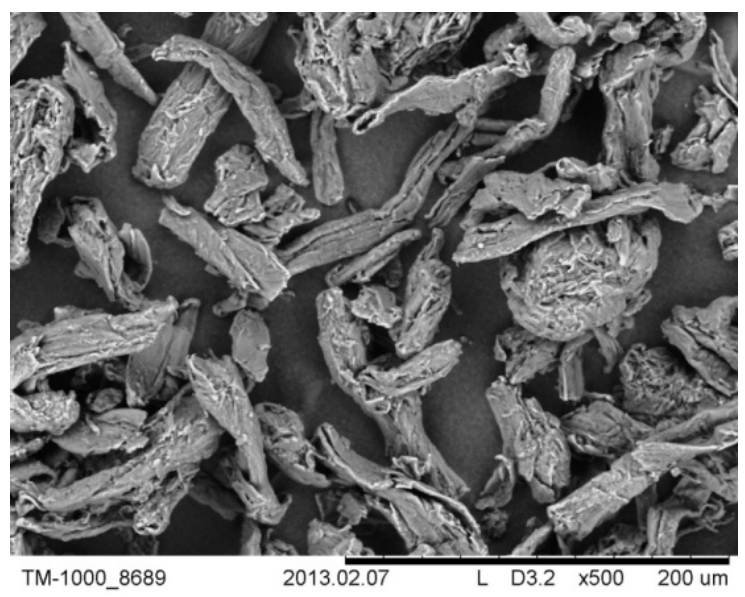

A - unitial cellulose

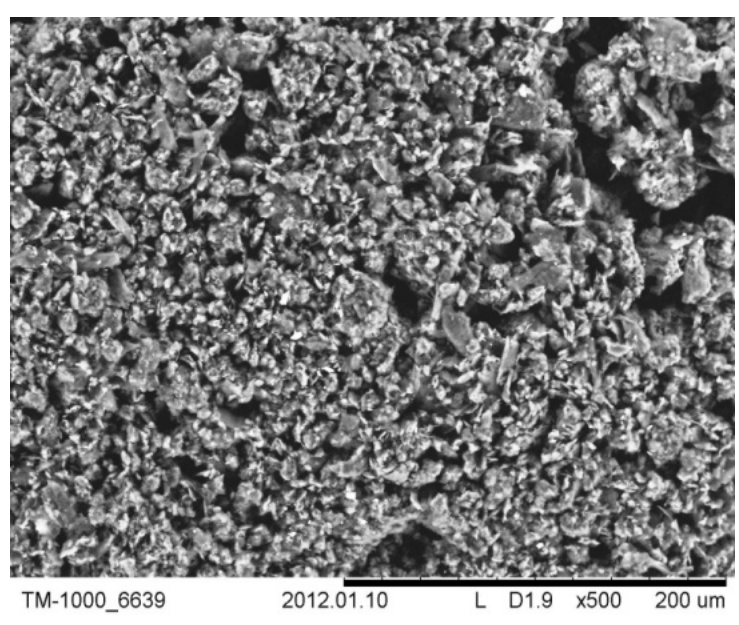

B - after milling during $1 \mathrm{~h}$

Fig. 8 SEM images of cellulose from birch wood (A) and cellulose after milling in planetary mill during $1 \mathrm{~h}$ 

during $24 \mathrm{~h}$. At these conditions the conversion of cellulose is $66 \mathrm{wt} \%$ in the presence of acid SBA-15 catalyst but oligosaccharides were mainly formed and the yield of glucose was only $8 \mathrm{wt} \%$ (Fig. 9a). The mechanical activation cellulose significantly increases its reactivity in hydrolysis and the almost $100 \%$ conversion of cellulose in the presence of acid SBA-15 catalyst reaches at $150{ }^{\circ} \mathrm{C}$ and reaction time $24 \mathrm{~h}$. At these conditions the yield of glucose is $42 \mathrm{wt} \%$ (Fig. 9 b).
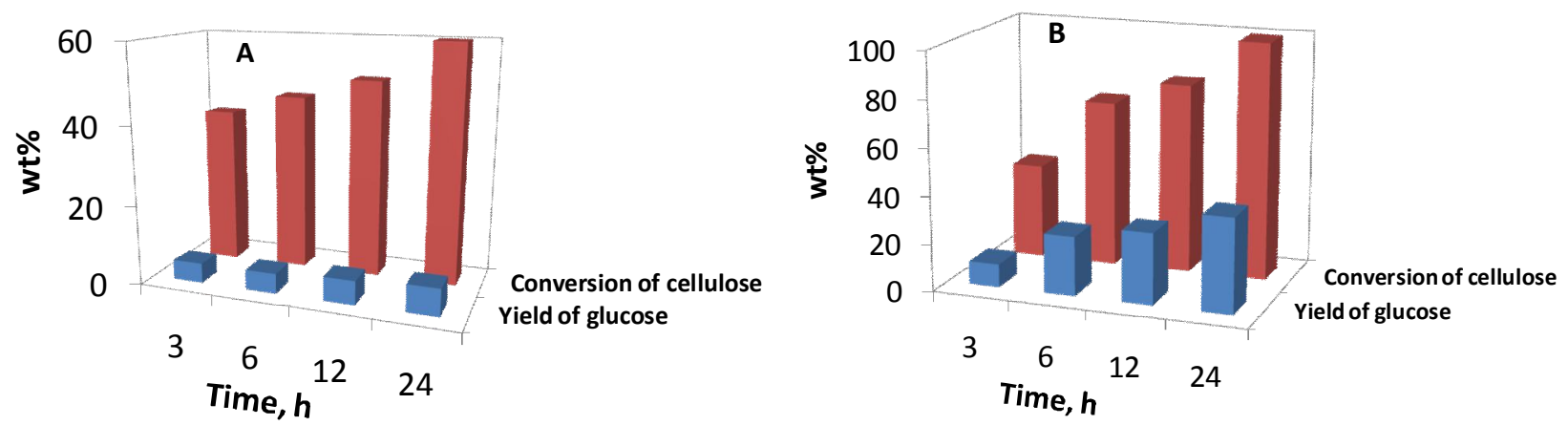

Fig. 9 Impact of time of hydrolysis of cellulose from birch wood (A) and cellulose after milling (B) on the conversion and yield of glucose in the presence of acid SBA- 15 catalyst at $150{ }^{\circ} \mathrm{C}$ and LWR 24

GC study of composition of hydrolysates from activated cellulose showed that the elevated temperatures $\left(150-170{ }^{\circ} \mathrm{C}\right)$ intensify the formation of furfural, 5-HMF and levulinic acid, which inhibit the fermentation of glucose to bioethanol.

Concentration of toxic components in the hydrolysates for bioethanol synthesis should not exceed (g/l): 0.5 - for furfural, 1.0 - for 5-HMF and 15.0 - for levulinic acid) (Huang et al. 2011; Zha et al.; Zha et al. 2012). In hydrolysates obtained from activated cellulose at $150{ }^{\circ} \mathrm{C}$ with acid SBA-15 catalyst the content of these toxic components are below the permissible values.

\section{Lignin conversion in supercritical alcohols}

The use of supercritical alcohols allows to raise the yield of the extractable products from lignin (Huang et al. 2014; Ma R., Hao et al. 2014). Lower aliphatic alcohols (ethanol, buthanol) are mainly chosen for lignin depolymerization for the reason that their critical temperatures are lower or close to the temperature range of lignin thermal destruction. In addition, bioethanol and biobutanol are produced by hydrolysis process in which lignin is wasted. Therefore, no additional chemicals should be used for lignin depolymerization into valuable chemicals.

The alcohols not only extract products of the thermal fragmentation of lignin but also can alkylate these products, preventing repolymerization processes (Heitner et al. 2010; Kim et al. 
In paper (Kuznetsov et al. 2015) the effects of sulfated $\mathrm{ZrO}_{2}$ and $\mathrm{ZrO}_{2}-\mathrm{Al}_{2} \mathrm{O}_{3}$ catalysts and acidic zeolite catalysts with various $\mathrm{Si} / \mathrm{Al}$ ratios on the thermal conversion of alkali lignin in supercritical ethanol at $300{ }^{\circ} \mathrm{C}$ and on the composition of the resulting products have been investigated. All of the catalysts increased lignin conversion into liquid products at $350-400{ }^{\circ} \mathrm{C}$. The catalysts reduced the concentration of phenol and its derivatives and increased the concentration of ethers in the liquid products. The highest lignin conversion and a highest yield of low-boiling liquid products were achieved at $350^{\circ} \mathrm{C}$ with the zeolite catalyst with $\mathrm{Si} / \mathrm{Al}=30$, which contains a high concentration of acid sites.

In the present paper the thermal conversion of acetone-lignin isolated from aspen wood was studied in supercritical butanol in the presence of $\mathrm{NiCuMo} / \mathrm{SiO}_{2}$ catalyst. Butanol is not converted to hydrocarbons in the absence of catalysts at temperatures $280-350{ }^{\circ} \mathrm{C}$. But at these conditions the catalyst $\mathrm{NiCuMo} / \mathrm{SiO}_{2}$ intensify the conversion of butanol and acetone-lignin to hydrocarbons. Some characteristics of used catalysts are given in Table 3.

Table 3 Catalysts for conversion of acetone-lignin in supercritical butanol

\begin{tabular}{cccc}
\hline Catalyst & Catalyst composition, $\mathrm{wt} \%$. & $\begin{array}{c}\text { Specific } \\
\text { surface area, } \\
\mathrm{m}^{2} / \mathrm{g}\end{array}$ & $\begin{array}{c}\text { Pore } \\
\text { volume, } \\
\mathrm{sm}^{3} / \mathrm{g}\end{array}$ \\
\hline $\mathrm{NiCuMo} / \mathrm{SiO}_{2} 20$ & $\mathrm{Ni}-46 ; \mathrm{Cu}-6.7 ; \mathrm{Mo}-11.7 ; \mathrm{Si}-15$ & 109 & 0.23 \\
$\mathrm{NiCuMo} / \mathrm{SiO}_{2} 30$ & $\mathrm{Ni}-41 ; \mathrm{Cu}-6.0 ; \mathrm{Mo}-17.8 ; \mathrm{Si}-13.3$ & 104 & 0.22 \\
\hline
\end{tabular}
hydrotreatment (Bulavchenko et al. 2010; Bykova et al. 2014). In the previous paper (Sharypov et al. 2015) the composition of liquid products of acetone-lignin conversion over $\mathrm{NiCu} / \mathrm{SiO}_{2}$ catalysts in supercritical butanol at $300{ }^{\circ} \mathrm{C}$ and pressure 2.4-5.0 MPa was studied by GC-MS method. It was found that the catalysts $\mathrm{NiCu} / \mathrm{SiO}_{2}$ intensify the reactions of butanol conversion and increase by 1.8 times the yield of hexane-soluble products. Liquid products of catalytic conversion of acetone-lignin have a high content of esters and a reduced concentration of methoxyphenols as compared to liquid products obtained in the absence of catalyst.

It was found that catalysts $\mathrm{NiCuMo} / \mathrm{SiO}_{2}$ are more active in acetone-lignin conversion than $\mathrm{NiCu} / \mathrm{SiO}_{2}$ catalysts (Fig. 10). The best of $\mathrm{NiCu} / \mathrm{SiO}_{2}$ catalyst allows to achieve the yield of hexane-soluble products up to $44 \mathrm{wt} \%$ (Sharypov et al. 2015) while catalyst $\mathrm{NiCuMo} / \mathrm{SiO}_{2}$ containing $30 \mathrm{wt} \%$ of $\mathrm{Mo}$ - up to $55 \mathrm{wt} \%$ 


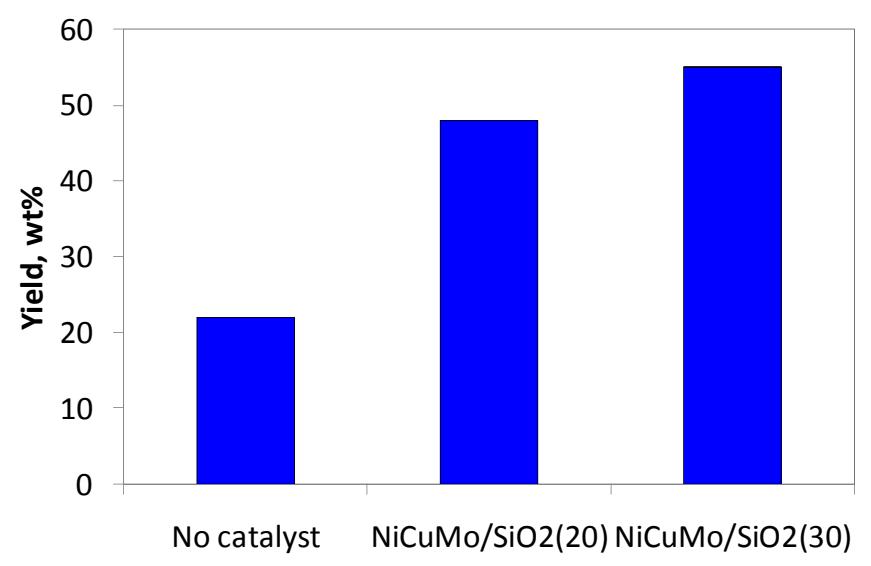

404

405

406

407

408

409

410

411

412

413

414

415

416

417

418

419

420

421

422

423

424

425

426

427

428

429

430

431

432

Fig. 10 Yield of hexane-soluble products obtained by acetone-lignin conversion in supercritical butanol at $300{ }^{\circ} \mathrm{C}$ over NiCuMo catalysts

\section{Integrated processing of hard wood}

Perspective directions in the development of innovative technologies of wood complex processing into valuable products are connected with a design of integrated processes which ensure the total utilization of all main components of a biomass (Cherubini et al. 200; de Long et al. 2013; Dajiang et al. 2014; Xu et al. 2016).

In particular, an integrated catalytic processing of hard wood based on wood catalytic oxidation with dioxygen to obtain a mixture of vanillin and syringaldehyde from lignin and levulinic acid from cellulose (Kuznetsov et al. 2008a).

An integrated process for obtaining liquid biofuels from aspen wood was also reported (Kuznetsov et al. 2013b). The process is based on the separation of a lignocellulosic feedstock into cellulose and low-molecular weight lignin (LMWL) followed by their conversion into two types of liquid biofuels, namely, hydrocarbon mixtures from lignin and bioethanol from cellulose.

In this paper the conversions of main components of hardwood biomass into valuable chemicals with the use of solid catalysts were described. The separate catalytic processes of hemicelluloses hydrolysis to xylose, wood oxidative fractionation into cellulose and soluble lignin, hydrolysis of cellulose to glucose for alcohols synthesis and lignin depolymerization in supercritical alcohols to liquid hydrocarbons can be employed for the biorefinery of hard wood, according to scheme, presented on Fig. 11.

Further improvement of the integrated processing of hardwood with the production of xylose, pure cellulose, glucose, alcohols and liquid hydrocarbons needs the development of more efficient solid catalysts for depolymerization of hemicelluloses, cellulose and lignin. 

supercritical alcohols

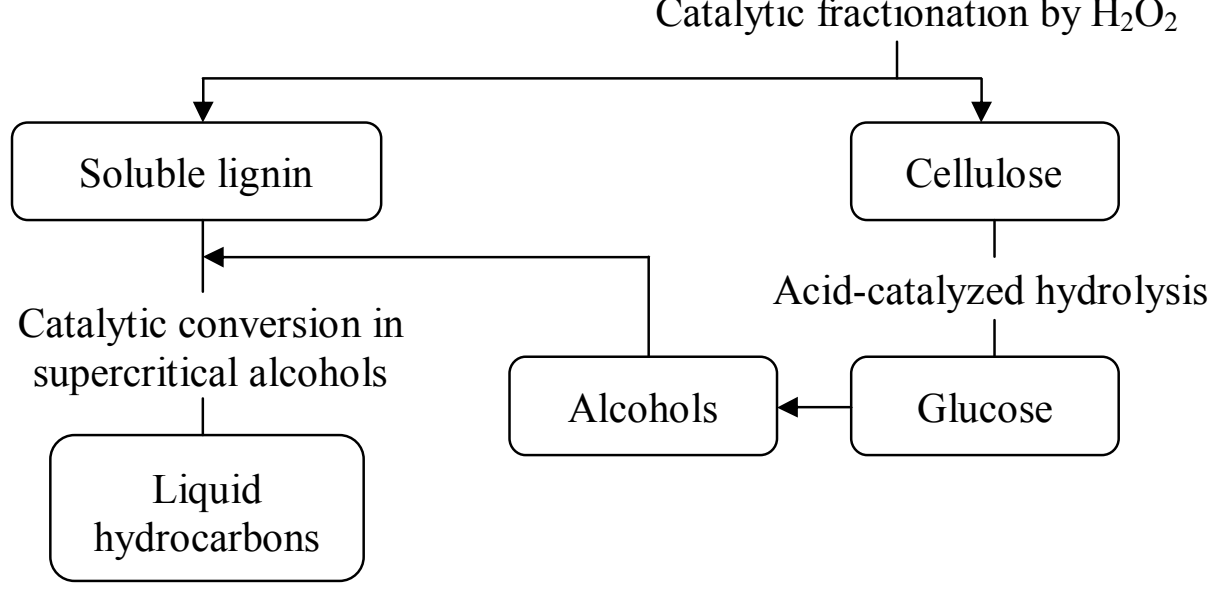

Fig. 11 Scheme of hardwood biorefinery based on heterogeneous catalysis proceses

$4633 \%$ reaching $77 \mathrm{wt} \%$ in the case of wood hydrolysis with $3 \% \mathrm{H}_{2} \mathrm{SO}_{4}$ catalyst. Solid catalysts are 464 active in hydrolysis of birch wood hemicelluloses only at temperatures higher $100{ }^{\circ} \mathrm{C}$. The 465 maximum yield of xylose $(72 \mathrm{wt} \%)$ is obtained at $150{ }^{\circ} \mathrm{C}$ with sulphated $\mathrm{ZrO}_{2}$ catalyst. This 466 yield is comparable to that obtained in the case of wood hydrolysis with $3 \% \mathrm{H}_{2} \mathrm{SO}_{4}$ catalyst at $467 \quad 100{ }^{\circ} \mathrm{C}$. 
To optimize the process of birch wood oxidative fractionation over mild conditions in the presence of $\mathrm{TiO}_{2}$ catalyst the influence of temperature, concentration of $\mathrm{H}_{2} \mathrm{O}_{2}, \mathrm{CH}_{3} \mathrm{COOH}$, liquid/wood ratio and time on the dynamics of lignin removal from wood was studied. Cellulosic product obtained at optimal conditions of birch wood fractionation $\left(100{ }^{\circ} \mathrm{C}, \mathrm{H}_{2} \mathrm{O}_{2}-0.5 \mathrm{wt} \%\right.$, $\mathrm{CH}_{3} \mathrm{COOH}-25 \mathrm{wt} \%$, LWR - 15) with an yield $48.2 \mathrm{wt} \%$ contains (wt\%): cellulose 93.7, hemicelluloses 5.5, lignin 0.5. The structure of birch wood cellulose corresponds to that of commercial microcrystalline cellulose. The soluble products of birch wood oxidative fractionation contain only small amounts of aromatic compounds, indicating deep oxidation of phenylpropane units of lignin at studied process conditions.

Cellulose obtained by catalytic oxidative fractionation of wood was used for the production of pure glucose hydrolysates for alcohols synthesis. The conversion of cellulose in hydrolysis at $150{ }^{\circ} \mathrm{C}$ during $24 \mathrm{~h}$ is $66 \mathrm{wt} \%$ in the presence of SBA-15 catalyst with $-\mathrm{SO}_{3} \mathrm{H}$ groups. But the oligosaccharides are mainly formed (yield of glucose is only $8 \mathrm{wt} \%$ ). At these conditions the conversion of cellulose mechanically activated in planetary mill reaches the almost $100 \%$ and the yield of glucose is $42 \mathrm{wt} \%$. In hydrolysates obtained from activated cellulose at $150{ }^{\circ} \mathrm{C}$ with acid SBA-15 catalyst the content of components which inhibit the fermentation of glucose to bioethanol (furfural, 5-HMF, levulinic acid) are below the permissible values.

The thermal conversion of acetone-lignin isolated from aspen wood was studied in supercritical butanol in the presence of $\mathrm{NiCuMo} / \mathrm{SiO}_{2}$ catalysts. Butanol is not converted to hydrocarbons in the absence of catalysts at temperatures $280-350^{\circ} \mathrm{C}$. But the catalysts intensify the conversion of butanol and acetone-lignin to hydrocarbons at these temperatures. The best $\mathrm{NiCuMo} / \mathrm{SiO}_{2}$ catalyst which contain $30 \mathrm{wt} \%$ of Mo allows to achieve the yield of hexanesoluble products up to $55 \mathrm{wt} \%$.

The studied heterogeneous catalytic processes of hemicelluloses and cellulose acid hydrolysis, wood oxidative fractionation, lignin depolymerization in supercritical alcohols can be employed for the green biorefieary of hardwood with producing of xylose, pure cellulose, glucose alcohols and liquid hydrocarbons.

Besson M, Gallezot P, Pinel C (2014) Conversion of biomass into chemicals over metal catalysts. Chem Rev 114(3):1827-1870

500 Boeriu CG, Fitigau FI, Gosselink RJA, Frissen AE, Stoutjesdijk J, Francisc P (2014) characterization of isolated fractions. Industrial Crops and Products 62:481-490 
Bulavchenko OA, Ermakov DYu, Lebedev MU, Yakovlev VA, Parmon VN (2010) Guaiacol hydrodeoxygenation in the presence of $\mathrm{Ni}$-containing catalysts. Catalysis in Industry $5: 45-52$

Bykova MV, Ermakov DYu, Khromova SA, Smirnov AA, Lebedev MYu, Yakovlev VA (2014) Stabilized Ni-based catalysts for bio-oil hydrotreatment: Reactivity studies using guaiacol. Catalysis Today 220-222:21-31

Cherubini F, Jungmier G, Wellish M, Willke T, Skiadas I, van Ree R, de Jong E (2009) Toward a common classification approach for biorefinery systems. Biofuels, Bioproducts\&Biorefining 172:534-546

Clark JH, Deswarte FEI (Eds) (2011) Introduction to Chemicals from Biomass. John Wiley\&Sons Ltd, Chichester

de Long E., Hidson A., Walsh P. (2013) Task 42. Biorefinery. Report International Energy Agency Bioenergy

Fengel D, Wegener G (1984) Wood: chemistry, ultrustructure, reactions. Walter de Gruter, Berlin

Heitner C, Dimmel D, Schmidt J (2010) Lignin and Lignans: Advances in Chemistry. CRC Press

$\mathrm{Hu}$ F, Jung S, Radauskas A (2012) Pseudo-lignin formation and its impact on enzymatic hydrolysis. Bioresour Technol 117:7-12

Huang H, Guo X, Li D, Liu M, Wu J, Ren H (2011) Identification of crucial yeast inhibitors in bio-ethanol and improvement of fermentation at high $\mathrm{pH}$ and high total solids. Bioresource Technol 102:7486-7493

Huang X, Koranyi TI, Boot MD, Hensen EJM. Catalytic depolymerization of lignin in supercritical ethanol. Chem Sus Chem 7:2276-2288

Kim JY, Park J, Hwang H, Kim JK, Song K, Choi JW (2015) Catalytic depolymerization of lignin macromolecule to alkylated phenols over various metal catalysts in supercritical tertbutanol. Journal of Analytical and Applied Pyrolysis 113:99-106

Kuznetsov B N, Tarabanko V E, Kuznetsova SA (2008a). New catalytic methods for obtaining cellulose and other chemical products from vegetable biomass. Kinetics and Catalysis 49:517-526

Kuznetsov BN, Kuznetsova SA, Danilov VG, Yatsenkova OV (2008b) Catalytic properties of $\mathrm{TiO}_{2}$ in wood delignification by acetic acid - hydrogen peroxide mixture. React Kinet Catal Lett 94:311-317

Kuznetsov BN, Sudakova IG, Garyntseva NV, Djakovitch L, Pinel C (2013a) Kinetic study of aspen-wood sawdust delignification by $\mathrm{H}_{2} \mathrm{O}_{2}$ with sulfuric acid catalyst under the mild conditions. Reac Kinet Mech Cat 110:271-280 
Kuznetsov BN, Sharypov VI, Grishechko LI, Celzard A (2013b) Integrated catalytic process for obtaining liquid fuels from renewable lignocellulosic biomass. Kinetics and Catalysis 54:P. 344-352

Kuznetsov BN, Sharypov VI, Chesnokov NV, Beregovtsova NG, Baryshnikov SV, Lavrenov AV, Vosmerikov AV, Agabekov VE (2015) Lignin conversion in supercritical ethanol in the presence of solid acid catalysts. Kinetics and Catalysis 56:434-441

Liu D and Chen EY-X (2014) Integrated catalytic process for biomass conversion and upgrading to C12 furoin and alkane fuel. ACS Catal 4:302-1310

Ma R, Hao W, Ma X, Tian Y, Li Y (2014) Catalytic ethanolysis of Kraft lignin into high-value small-molecular chemicals over a nanostructured $\alpha$-molybdenum carbide catalyst. Angew Chem Int Ed 53:7310-7315

Maki-Arvela P, Holbom B, Salmi T, Murzin DYu (2007) Recent progress in synthesis of fine and specialty chemicals from wood and other biomass by heterogeneous catalytic processes. Catal Rev 49:197-340

Nelson V (2011) Introduction to renewable energy. CRC Press, London, New York

Park S, Baker JO, Himmel ME, Parilla PA, Jonson DK (2010) Cellulose crystallinity index: measurement techniques and their impact on integrating cellulose performance. Biotechnol Biofuels 3:10

Raveendran SN., Guliants V (2009) Recent developments in catalysis using nanostructured materials. Applied Catalysis A: General 356:1-17

Ruiz-Matute AJ, Hernandez-Hernandez O, Rodrigues-Sanchez S, Sanz MI, Martinez-Gastro I (2011) Derivatization of carbohydrates for GC and GC-MS analysis. Journal of Chromatography B 879:1226-1240

Serrano-Ruiz JC, Dumesic JA (2011) Catalytic routes for the conversion of biomass into liquid hydrocarbon transportation fuels. Energy Environ Sci 4:83-99

Sharypov VI, Kuznetsov BN, Yakovlev VA, Beregovtsova NG, Baryshnikov SV, Djakovitch L, Pinel C (2015) Composition of liquid products of acetonlignin conversion over $\mathrm{NiCu} / \mathrm{SiO}_{2}$ catalysts in supercritical butanol. Journal of Siberian Federal University. Chemistry $8: 465-475$

Sixta H (2006) Hand book of pulp Wiley-VCH Verlug GmbH\&Co, Weinheim, Germany

Sjoöstroöm E, Alern R (eds) (1999) Analytical methods of wood chemistry. Pulping and Papermaking. Springer-Verlag, Berlin

Taherzadeh MJ, Karimi K (2007) Acid-based hydrolysis processes for ethanol from lignocellulosic materials: A review. BioResources 2:472-499

Toshio O (2002) Water-tolerant solid acid catalysts. Chem Rev 102:3641-3666 
573 Suchy M, Argyropoulos D (2001) Catalysis and activation of oxygen and peroxide 574 delignification of chemical pulp: A review. ACS Symposium Series 785:2-43

575 Van de Vyver S, Geboers J, Jacobs PA, Sels BF (2011) Recent advances in the catalytic conversion of cellulose. Chem Cat Chem 3:2-99

$577 \mathrm{Xu} \mathrm{J}$, Xie X, Wang J, Jiang J (2016) Directional liquefaction coupling fractionation of $578 \quad$ lignocellulosic biomass for platform chemicals. Green Chem 18:3124-3138

579 Zakzeski J, Bruijnincx PCA, Jongerius AL, Weckhuysen BM (2010) The catalytic valorization 580 of lignin for the production of renewable chemicals. Chem Rev 110:3552-3599

581 Zha Y, Muilwijk B, Coulier L, Punt PJ (2012) Inhibitory compounds in lignocellulosic biomass 582 hydrolysates during hydrolysate fermentation processes. J Bioprocessing \& Biotechniques $2: 112-122$

584 Zha Y, Westerhuis JA, Muilwijk B, Overkamp KM, Nijmeijer BM, Coulier L, Smilde AK, Punt 585 PJ (2014) Identifying inhibitory compounds in lignocellulosic biomass hydrolysates using 586 an exometabolomics approach. BMC Biotechnology 14:22-38

587 Zheng Y, Pan Z, Zhang R (2009) Overview of biomass pretreatment for cellulosic ethanol 588 production. International Journal of Agricultural and Biological Engineering 3:51-68 